\title{
The little-known Fissidens axilliflorus Thwaites \& Mitt. (Fissidentaceae: Bryophyta) - new to the moss flora of India
}

\author{
R Sreebha ${ }^{1} \&$ A E D Daniels ${ }^{2 *}$ \\ ${ }^{1}$ Department of Botany, V. V. Vanniaperumal College for Women (Autonomous), Virudhunagar - 626 001, Tamil Nadu, India \\ ${ }^{2}$ Bryology Laboratory, Department of Botany \& Research Centre, Scott Christian College (Autonomous), Nagercoil - 629 003, Tamil Nadu, India \\ *Email: dulipdaniels@yahoo.co.uk
}

\section{ARTICLE HISTORY}

Received: 16 June 2020

Accepted: 16 September 2020

Published: 01 October 2020

KEYWORDS

Fissidens axilliflorus; India; Western

Ghats; Tamil Nadu
ABSTRACT

Fissidens axilliflorus, so far known from Sri Lanka and Laos, has been discovered in the Western Ghats in India. A description with line drawings, a photo plate and a key to distinguish F. axilliflorus from the similar F. crenulatus are provided.

\section{Introduction}

Currently, there are about 450 species of Fissidens Hedw. World-wide (1). In India there are 78 valid species (2) while in the Western Ghats there are 59 (3). The discovery of Fissidens axilliflorus Thwaites \& Mitt. while surveying the Southernmost Western Ghats for bryophytes adds one more species to the genus in India and the Western Ghats raising the number to 79 and 60 respectively. Thwaites and Mitten (4) described Fissidens axilliflorus based on a material collected from Ceylon. This species was later reduced to a synonym of F. crenulatus Mitt. (5). However, it was resuscitated as $F$. axilliflorus since it differs from $F$. crenulatus in possessing sharply unipapillose laminal cells and a one-cell thick (unistratose) limbidium (6). In addition, differentiating and consistent features such as the presence of a wedge-shaped dorsal lamina base and papillose spores observed in the present material can be attributed to the distinctiveness of this species.

\section{Taxonomic key distinguishing $F$. axilliflorus from F. crenulatus}

1a. Dorsal lamina wedge-shaped at base; leaf laminal cells sharply mammillose to unipapillose, rarely bipapillose; spores papillose. F. axilliflorus 1b. Dorsal lamina rounded at base; leaf laminal cells bluntly mammillose with 1 or 2 low papillae; spores sparsely papillose F. crenulatus

Fissidens axilliflorus Thwaites \& Mitt., J. Linn. Soc. Bot. 13: 325. 1873; Tad. Suzuki \& Z. Iwats., Hattoria 4: 52. 2013. - Type: Ceylon (Sri Lanka), Central Province, G.H.K. Thwaites 8, s.d. Herb. Mitt. (NY). (Figs 1 \& 2).

Plants dioicous, scattered or in loose mats, green, pinnate, $4-9 \mathrm{~mm}$ tall, $1.5-1.7 \mathrm{~mm}$ wide. Stems simple, $0.098-0.14 \times 0.084-0.10 \mathrm{~mm}$ in cross section, ovate, $8-10$ cells across, with a faint central strand, greenish-white above, pale reddish-brown below; cortex 1-2-layered, with 4-12 × 6-16 $\mu \mathrm{m}$, thick-walled cells; medullary cells $12-20 \times 14-16 \mu \mathrm{m}$, thin-walled; axillary nodules not developed. Rhizoids basal. Leaves 4-10 pairs, imbricate to distant, slightly crispate when dry, obliquely spreading when moist, oblong to oblong-lingulate, 0.4$1.3 \times 0.1-0.2 \mathrm{~mm}, 4$ to 5 times as long as wide, narrowing dorsally, reaching the point of insertion or ending well above, wedge-shaped at base, not decurrent, crenulate at margin throughout due to projecting papillae, acute to acuminate at apex; apical and median cells 6-10 × 4-8 $\mu \mathrm{m}$, moderately thick-walled, sharply mammillose to unipapillose, sometimes with a few bipapillose ones; basal cells $\quad 12-20 \times 10-16 \mu \mathrm{m}$, quadrate-rectangular. Limbidium present on vaginant laminae of welldeveloped leaves, reaching the apex of vaginant laminae

(C) Sreebha \& Daniels(2020). This is an open-access article distributed under the terms of the Creative Commons Attribution License, which permits unrestricted use, distribution and reproduction in any medium, provided the original author and source are credited (https://creativecommons.org/licenses/by/4.0/).

To cite this article: Sreebha R, Daniels A E D. The little-known Fissidens axilliflorus Thwaites \& Mitt. (Fissidentaceae: Bryophyta) - new to the moss flora of India. Plant Science Today. 2020;7(4):560-563. https://doi.org/10.14719/pst.2020.7.4.843 


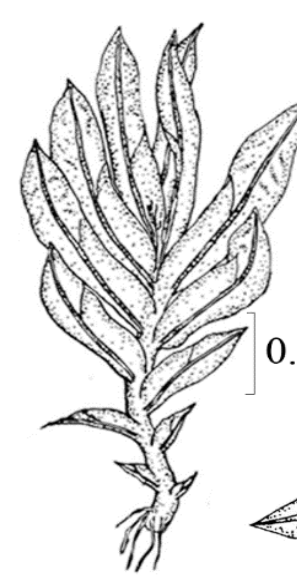

A

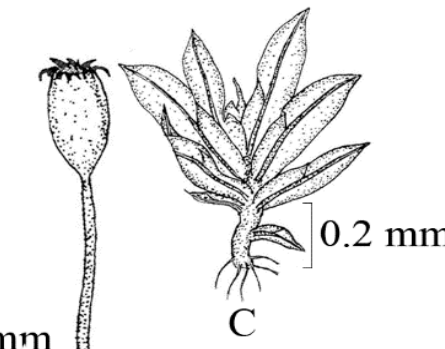

$\mathrm{C}$
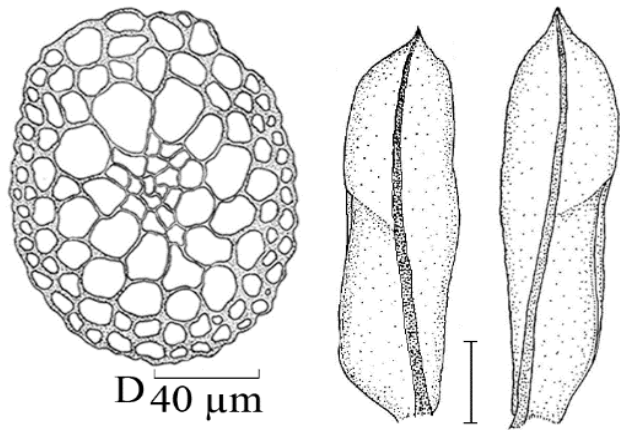

$0.2 \mathrm{~mm}$

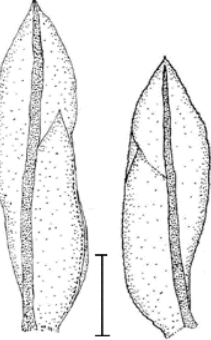

$0.2 \mathrm{~mm}$

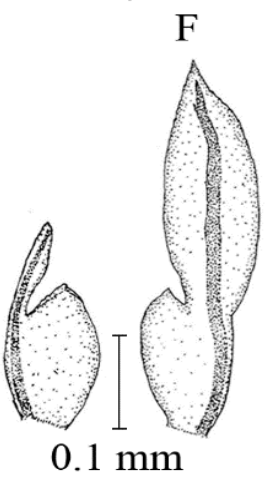

$0.3 \mathrm{~mm}$

$\mathrm{G}$

$\mathrm{H}$
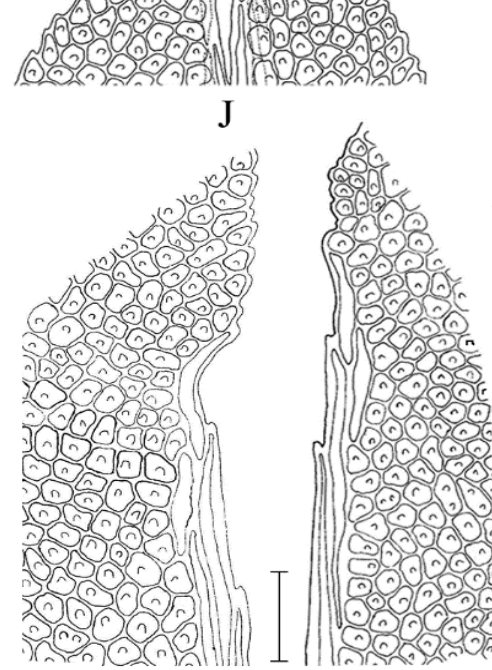

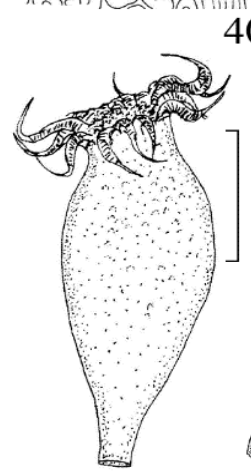

Q

$40 \mu \mathrm{m}$

$\mathrm{M}$

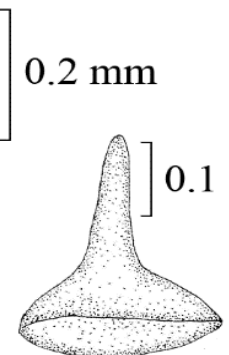

$\mathrm{R}$

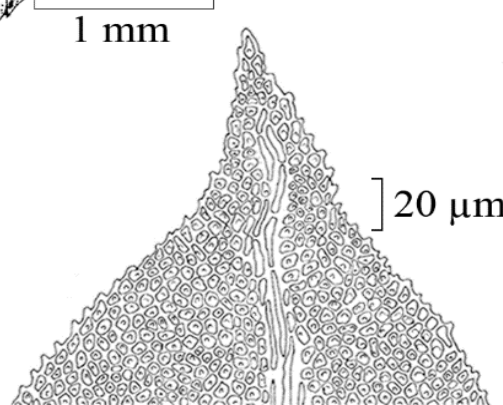

$\mathrm{K}$

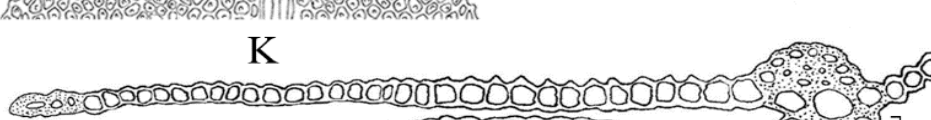

60000000000000000000000000000 13:

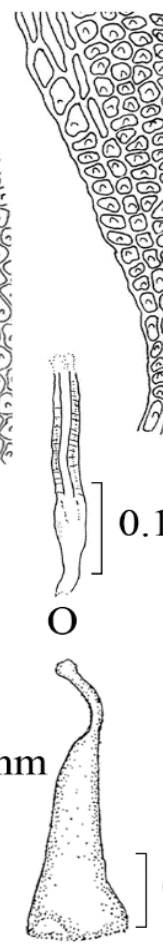

$\mathrm{S}$
$0.1 \mathrm{~mm}$

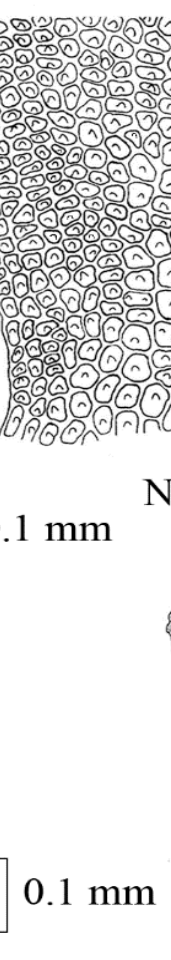

Fig. 1. Fissidens axilliflorus Thwaites \& Mitt. A. basal cells $\mathbf{O}$. Archegonium P. Cross-section of seta $\mathbf{Q}$. Capsule with peristome teeth $\mathbf{R}$. Operculum $\mathbf{S}$. Calyptra T. Peristome teeth outer side U. Peristome teeth inner side V. Spores (R. Sreebha 211, 260).

or ending 8-12 cells below, marginal or weakly and irregularly intramarginal towards the base, composed of 2-4 rows of hyaline, elongate, smooth, thin-walled cells, unistratose, absent on young leaves and leaves of male plant; vaginant laminae $1 / 3$ as long as leaf, subequal to unequal; costae ending below leaf apex to shortly excurrent, with 2 or 3 guide cells in cross section. Perigonia and perichaetia terminal; perigonia bud-like, on $0.6-1 \mathrm{~mm}$ tall male plants at base of female plants (rhizautoicous); perichaetial leaves longer and narrower than vegetative ones, $1-1.3 \times 0.16-0.25 \mathrm{~mm}$, broadly constricted at middle, crenulate at margin due 

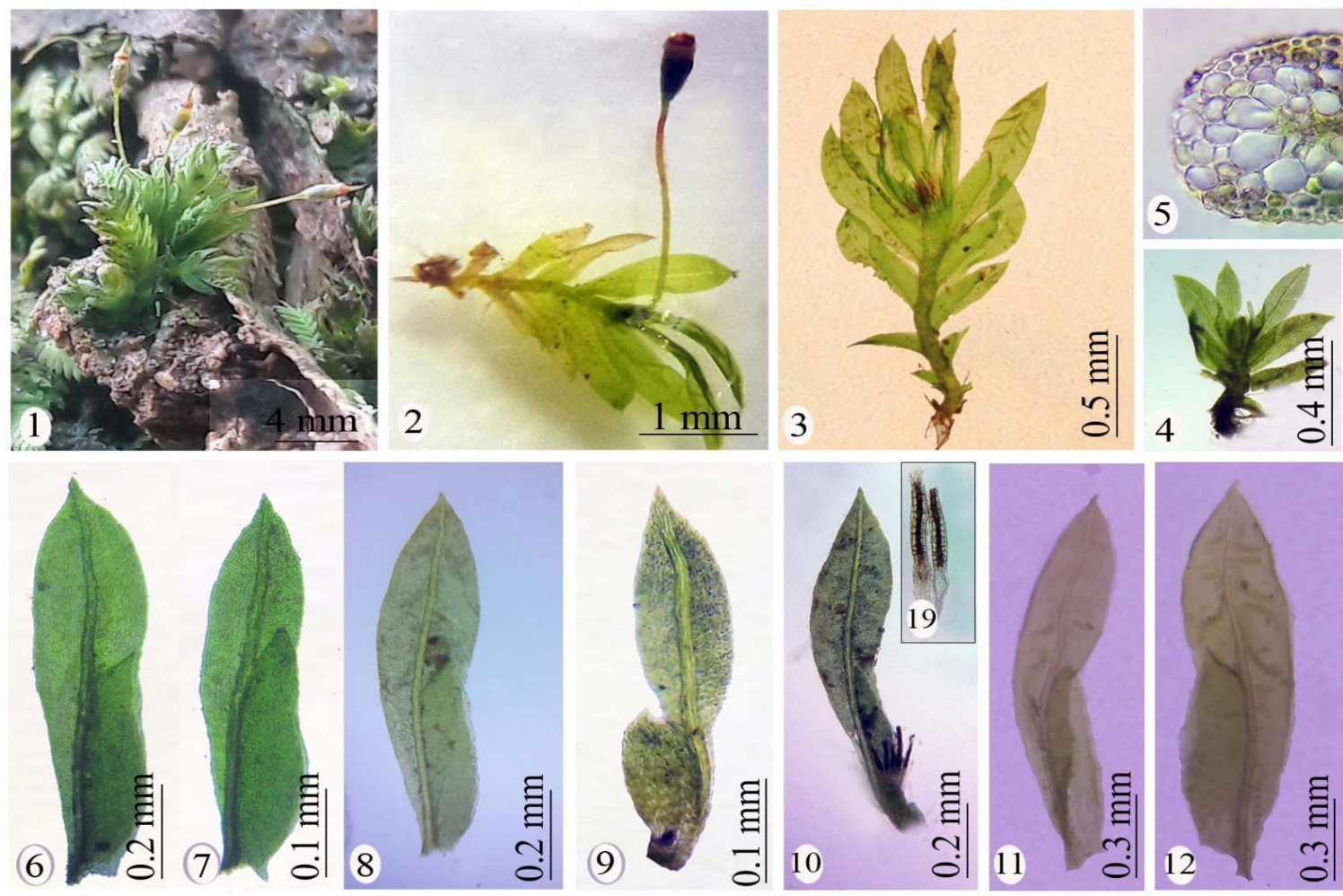

(9)
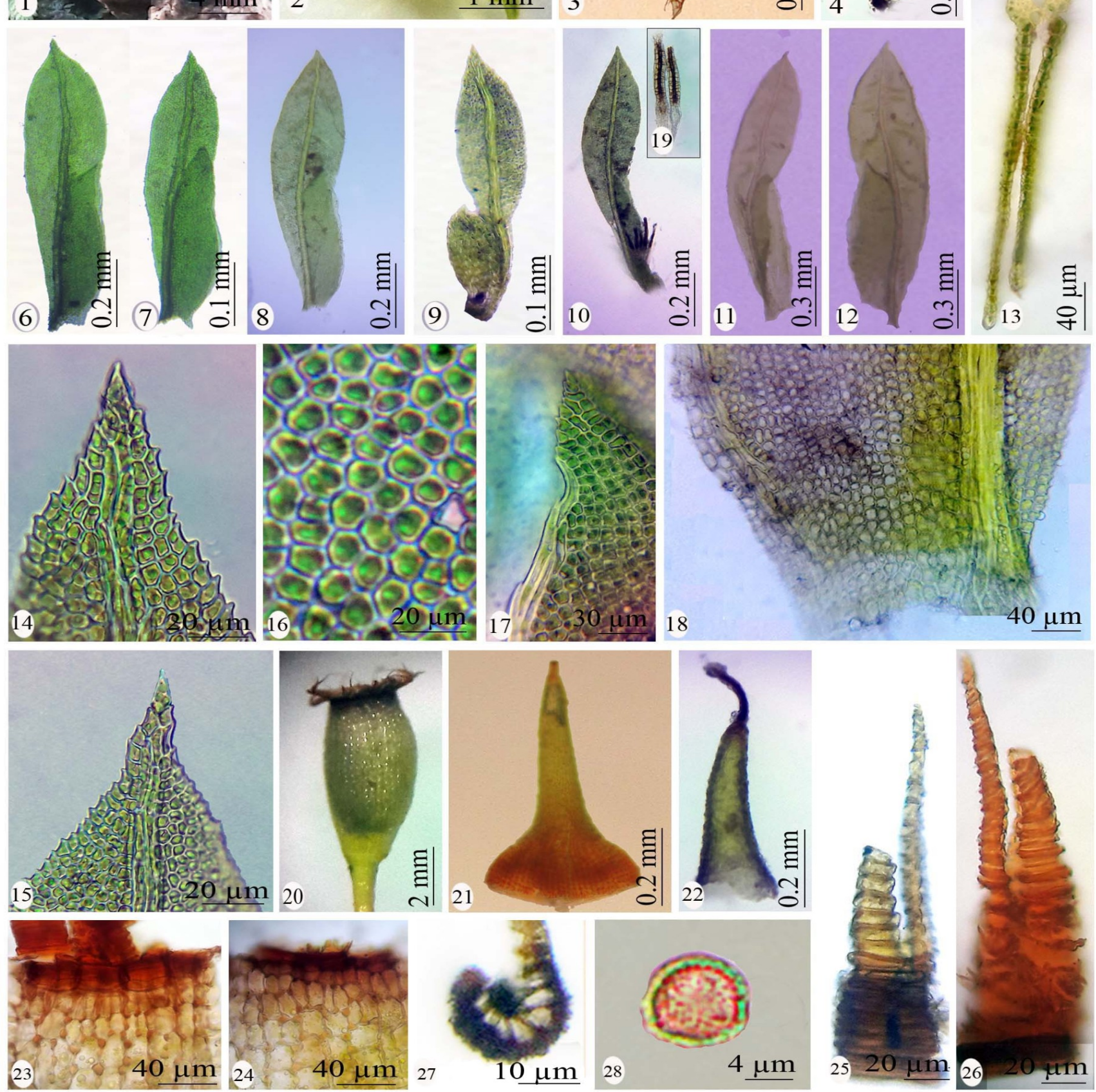

Fig. 2. Fissidens axilliflorus Thwaites \& Mitt.1. Habitat 2. Sporophytic plant 3. Female plant with archegonia 4. Male plant 5. Cross-section of stem 6-8. Leaves 9. Perigonial leaf 10. Perichaetial leaf with archegonia 11-12. Perichaetial leaves 13. Cross-section of leaf 14-15. Leaf apical cells 16. Leaf median cells 17. Ending of limbidium 18. Leaf basal cells 19. Archegonia 20. Capsule 21. Operculum 22. Calyptra 23-24. Capsule outer and inner walls respectively 25. Peristome teeth outer side 26. Peristome teeth inner side 27. Side view of the undivided basal part of peristome 28. Spore (R. Sreebha 211,260).

to projecting papillae. Sporophytes apical. Setae $4-5$ $\mathrm{mm}$ long, erect, smooth. Capsules erect, asymmetric, $0.5-0.62 \times 0.32-0.34 \mathrm{~mm}$, ovoid-cylindric; operculum reddish-brown, $0.3-0.4 \mathrm{~mm}$ long; calyptrae cucullate, slightly scabrous. Peristome teeth of scariosus-type, 200-260 × 36-38 $\mu \mathrm{m}$, reddish-brown. Spores 8-12 $\mu \mathrm{m}$, globose, papillose, pale brown. 
Habitat: Lignicolous (on roots of Cocos nucifera L. stumps); terricolous in degraded evergreen forests, ca $90 \mathrm{~m}$ above msl.

Distribution: Laos, Sri Lanka and India (3): the Western Ghats, Tamil Nadu, Kanniyakumari Dt. (present study) (Fig. 3).

Specimens examined : India, Western Ghats, Tamil Nadu, Kanniyakumari Dt., Kizhakkambhagam, Ponmanai, 8 35' 0.62" N \&77 32' 0.84", ca 90 m, 05 October, 2019, R. Sreebha 211 (SCCN); 06 December, 2019, R. Sreebha 220 (SCCN); 14 January, 2020, $R$. Sreebha 260 (SCCN).

\section{Discussion}

In a study (6), it was stated that Fissidens axilliflorus is characterized by sharply unipapillose laminal cells, percurrent costae and a one-cell thick (unistratose) limbidium. However, the present collection shows slight variations from these observations such as the laminal cells being sharply mammillose to unipapillose, sometimes bipapillose and the costae ending below leaf apex to slightly excurrent. Moreover, the species is very similar to F. crenulatus. Both have mammillose laminal cells and unistratose limbidia on the vaginant laminae of all welldeveloped leaves. However, the limbidium of $F$. crenulatus is highly cartilaginous and yellowish whereas that of F. axilliflorus is hyaline and consists

\section{Acknowledgements}

The authors thank the Tamil Nadu State Forest Department for permission to explore the study area and the Principal, Scott Christian College (Autonomous), Nagercoil for facilities. AEDD is thankful to Dr. M. A. Bruggeman-Nannenga (the Netherlands), for help in identifying the specimen, relevant literature and comments on the manuscript.

\section{Conflict of interests}

The authors declare that they have no competing interests.

\section{References}

1. Crosby MR, Magill RE, Allen, B, He S. A checklist of the mosses. St. Louis: Missouri Botanical Garden; 2000. P. 1-320.

2. Manjula KM, Manju CN, Rajilesh VK, Chandini VK. Fissidens linearis (Fissidentaceae: Bryophyta) - a new record for India. Acta Botanica Hungarica; 2015; 57: 165-68. https://doi.org/10.1556/ABot.57.2015.1-2.12

3. Manjula KM. Taxonomic studies on the family Fissidentaceae Schimp. (Bryophyta) of the Western Ghats. Ph.D. thesis, University of Calicut, Kozhikode; 2018. P.1-489.

4. Mitten W. New species of Musci collected in Ceylon by Dr. Thwaites. Journal of the Linnean Society, Botany 1873; 13: 293326. https://doi.org/10.1111/j.1095- 8339.1873.tb00096.x
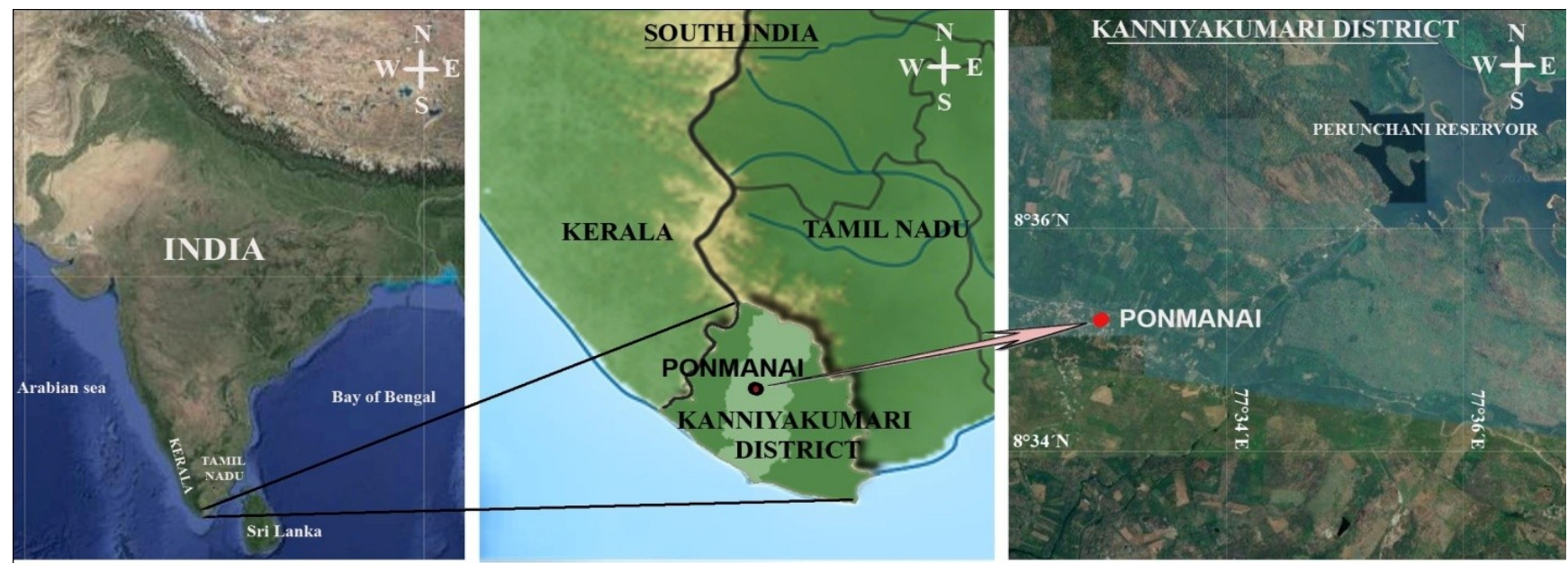

Fig. 3. Location-map of Fissidens axilliflorus Thwaites \& Mitt. in India

of thin-walled cells. Further differences between the two species are given in the key above.

In a study (7), there merged the bryoides- and scariosus-type of peristome into one, the fissidenstype and therefore indicated the peristome type in Fissidens axilliflorus as a fissidens-type (6). However, here we follow another study (8) and indicate this peristome as a scariosus-type.

\section{Authors' contributions}

RS: Collection, dissection and preparation of figure and photographic plates; AEDD: Preparation of the MS.
5. Li Z-h, Iwatsuki Z. Fissidentaceae. Moss flora of China, English version 2001; 2: 3-67.

6. Suzuki T, Iwatsuki Z. Collections of Fissidens (Fissidentaceae, Bryopsida) made by Messrs. T. Kamiyama \& K. Shiina in Laos. Hattoria 2013; 4: 47-70.

7. Suzuki T, Iwatsuki, Z. A new approach to the infrageneric classification of the genus Fissidens (Fissidentaceae, Bryopsida). Hikobia 2007; 15: 67-85.

8. Bruggeman-Nannenga MA., Berendsen W. On the peristome types found in the Fissidentaceae and their importance for the classification. Journal of the Hattori Botanical Laboratory 1990; 68: 193-234. 